UDC 327::911.3(497)“"2019/2021““

DOI: https://doi.org/10.18485/iipe_ria.2021.72.1182.1

Biblid 0543-3657, 72 (2021)

Vol. LXXII, No. 1182, pp. 5-26

Original article

\title{
GEOPOLITICS OF THE BALKANS: 2019-2021
}

\author{
Slobodan JANKOVIĆ
}

\begin{abstract}
Geopolitical analysis of the policies of the great powers over and in the Balkans in the period of three years is the object of this paper. The author initiates by retelling an event in 2019, indicative of one of the two theses of the text, namely that the US has returned to the Balkans. The second is the assumption, originally launched by the Russian geopolitician Dugin, that the Balkans are one of two monitors of world politics. The text is divided into five chapters. In the introductory part, the author defines his hypothesis and opts for Italian neoclassical geopolitical thought as a theoretical framework. The second chapter overviews basic socio-historical and geographical features of the Peninsula relevant for geopolitical understanding, while the third part of the text puts local political action of both external and internal actors into a broader geopolitical context. The fourth part is the most extensive and represents an overview of the most significant political actions of the great powers - Russia, the United States and China, and Germany, Turkey, and local countries. The conclusive part answers positively to Dugin's assumption and confirms the thesis that great powers' politics in the Balkans has regained importance for the US. Keywords: Geopolitics, Balkan politics, Russian Balkan policy, Belt and Road, U.S. initiatives in the Balkans, Serbia, Greece, German Balkan politics.
\end{abstract}

\section{A THIRD-GRADE DIGNITARY AND AMERICAN RETURN TO THE BALKANS}

The American novelist and diplomat Matthew Palmer participated in a local security forum in the late summer of 2019 in a small European country called Slovenia. His assignment was to deliver the tasks and check the students covering

\footnotetext{
${ }^{1}$ Senior Research Fellow, Head of the Centre for Neighbourly and Mediterranean countries; Institute of International Politics and Economics (Serbia). Email: slobodan@diplomacy.bg.ac.rs The paper presents the findings of a study developed as part of the research project entitled 'Serbia and challenges in international relations in 2021', financed by the Ministry of Education, Science, and Technological Development of the Republic of Serbia, and conducted by the Institute of International Politics and Economics, Belgrade.
} 
local positions in the formally independent countries in South-East Europe. And he did it well. The message was that the Balkans was again important for U.S. policy, well at least for the then President and the latter presidential candidate, Donald Trump. He had an opportunity to receive expressions of obedience and promises that the tasks would be fulfilled by a delegation from a country that recently changed its name in order to be accepted as a formal part of the club that provides units for its lord and follows instructions on internal and foreign behaviour. He also met with representatives of Serbia and Kosovo Albanians, who, under the protection of the American lord, managed to present themselves in some circles as an independent country. This deputy assistant, a third-grade dignitary of the empire, met with presidents and ministers since then and urged them to continue with dictated reforms or to reach a normalisation (between, as he said, Serbia and Kosovo), in order to become a part of the European Union. Nobody asks publicly how come officials of the United States are offering a path toward the European Union if this Union is not in some kind of tributary relationship with official Washington? A detailed description of this visit was offered by an Italian university review under the title "USA: Return of Washington in Balkan Geopolitics". (Ceremigna, 2019).

This episode partially depicts the quality of relations in the Balkans that may be analysed in the context of Balkan geopolitics. Geopolitics emphasizes analysis of the relations between some countries, regions, or territories in general with regard to their features or geographical characteristics relevant to international political significance, at local, macro-regional, and global levels. As there were enough studies on Balkan geopolitics in the previous period, the period studied in this study will start from the supposed return of the Americans in 2019.

Recently, a political risk consultant, originally from the Balkans, Gordon Bardos, launched a claim about the small importance, almost irrelevance, of the region for U.S. policy:

"From a realist perspective, the region should be of little interest to the United States. None of the countries in south eastern Europe have nuclear weapons; none are a military threat to the United States; none of these countries have oil, and waves of Balkan refugees are not going to come streaming over U.S. borders. The region is irrelevant to the U.S. economy; in 2020, U.S. trade with all of the Western Balkans (Albania, Bosnia and Herzegovina, Croatia, Kosovo, Montenegro, Northern Macedonia, Serbia) was less than one-tenth of 1 percent of total U.S. foreign trade." (Bardos 2021).

Nonetheless, there is evidence of a certain comeback, as the US never really left the region, but it was out of focus for a while. During that period, the war on terrorism, economic crises, and similar overshadowed business in South-East Europe. Hence, why did Washington return to Balkan geopolitics and why did Brussels agree to common action in this small part of Europe and an even smaller 
part of the world? The answer to this question may corroborate the assumption of the famous Russian geopolitician Aleksandr Dugin that the Balkans represent one of two monitors of world geopolitics (the other is the Middle East). (Glišić, $2020,49)$. An analysis of the great powers' interests in the region is part of the answer to this claim.

Italian neoclassical geopolitical thought, in combination with Lake's concept of international hierarchy, will be used as a theoretical framework best suited to explain the motives and objectives of the behaviour of geopolitical actors because it incorporates the will (volontà) of those holding political power, cultural and historical context, and, lastly, geographic characteristics. This thought could be summarized in the phrase that "it is the spirit that rules over the material", as said by Gofreddo Jaja (see: Janković 2020, 107-8).

One could argue that in the region where political relations are impregnated with history, constructivism would be more suited. Yet, the constructivist approach lacks to define a reality that depends not only on perceptions but also on the will of the actors and different layers of analysis. For example, Serbia and Russia indeed have a common history of cooperation and friendship through centuries that cannot be explained by mere Machiavellian calculus. Bulgaria switched sides several times in the past hundred years. Greece, due to the nature of its maritime borders and for historical reasons, has conflicting relations with Turkey. Greece, with its long heritage, just like other Balkan nations, lays claim to territories outside its national borders. Also, the Turkish Neo-Ottomans view the Balkans as their core imperial land (Todorova 2009, 50). Ergo, more reliance on history induced by real events and not only perceptions of the geographic factors in the politics of the contact region favours Italian neoclassical geopolitical thought.

Marconi, a representative of the Italian neoclassical school, indicates that thought and historical experience shape space. (Marconi 2012, 53). Putting the will, thoughts and experience of those who plan and execute politics in relation to history and geography explains the behaviour of Turkey, Russia, and other countries. Germany and Italy are two main economic partners of the Balkan countries, and yet they are superseded by Washington. The European Union is part of the liberal international order where the US is the "core guarantor". (Lake, Martin and Risse 2021, 238). In the international hierarchy led by Washington, Germany is a weak but enduring American protectorate and Italy is one of the most subordinate states. (Lake 2009, 55, 86).

\section{SOCIO-HISTORICAL AND GEOGRAPHICAL FEATURES OF THE BALKANS}

The historical and cultural context of the Balkans refers to it as a mainly orthodox Christian peninsula with a significant Muslim and a less significant 
Roman Catholic minority. The historical geography of the region is important for the world and, in particular, for European history. It is old Europe, as the oldest European cultures were born in the Balkans. Lepenski vir, Starčevo, Vinča, and afterwards, Minoan and Greek cultures were born and flourished here. The importance of this region for the early history of the old continent and its antiquity is hard to overestimate. The current characteristics of the contact or crossing point of the Balkans regarding religions were formed during a long period of time, starting with the spread of Christian teachings.

Christianisation since the $1^{\text {st }}$ century $\mathrm{AD}$, and the partitioning of the peninsula along the religious line since 1054, divided it between Orthodox Christians and Roman Catholics. Ottoman invasions brought Islamisation of part of the population and complicated divisions. Slavic peoples dominate the area, although they are religiously and politically divided. The Serbs, Bulgarians, and Slavic Macedonians are Orthodox, the Croatians are Catholics, and there are Slavic Muslim populations, part of which since the 1990s, have defined themselves as Bosnians irrespective of historical ties with the territory called Bosnia (a significant part of today's Bosnia and Herzegovina), in Bosnia, Montenegro, Serbia, and North Macedonia. Albanians have a particular ethnic origin. They are mainly Muslims, with a strong minority of Catholics and Orthodox Christians in Albania and a large swath of atheists among Albanians in Albania. The overwhelming majority of them in the Serbian secessionist province of Kosovo and Metohija and in North Macedonia are Muslims. Romanians have mixed origins, mostly of Romanised Balkan tribes, and are predominantly Orthodox with a Catholic and Greco-Catholic minority. Finally, Greeks are Orthodox. Along this line is the conclusion of Samuel Huntington that "Europe ends where Western Christianity ends and Islam and Orthodoxy begin.” (Huntington 1996, 158).

Religion was, as the great Serbian historian Ekmečić would say, a watershed for nations and peoples in the Balkans. (Ekmečić, 2010, 201) The process of making and reimagining nations in the Balkans did not stop, and it still evolves in parallel with the realignment of borders. British Diplomat Timothy Less has argued for years that borders in the Balkans are problematic because they do not follow ethnic (and religious) divisions. (Less 2016).

"Balkans borders are the result of the fight for the national liberation that initiated in the region with the Serbian uprising in 1804. It was followed in 19 century with Greek, Romanian and Bulgarian fight for national freedom. Albanians won the independence in 1912 as a result of the defeat of Ottomans and the loss of its Balkan provinces. Still, Albania was established in it borders as a result of imperial policies of Austro-Hungarian monarchy, of British empire and of Italy directed against Serbia's presence on the Adriatic shores. Creation of the Kingdom of Serbs, Croats and Slovenes (it was nominated Yugoslavia in 1929) solved the Serbian national question 
(unification of Serbian territories). Croatians, Slovenes, Muslims in Bosnia and Macedonians achieved their national states out of the dissolution of Socialist Yugoslavia in 1991 and 1992... New states and correspondingly, new borders emerged after administrative lines of federal units inside old Yugoslavia (as was the case of ex USSR)." (Janković 2010,168).

Communist created administrative lines were cut across the ethnic presence of Serbian and other people in what was previously Socialist Yugoslavia. When they turned into international borders, it was one of the ignitions of war that served the great powers and, in particular, NATO to impose its newly found raison d'être. ${ }^{2}$

Historical and geographic features also refer to the name of the Peninsula. In the past quarter of a century, the EU and the US introduced a newly found syntagma - the Western Balkans. As Despotović and Glišin would say, to name something is to wield power, recalling the analysis of Kljakić who holds that naming a territory represents a decision to influence future political orientation (of political entities, S, J.). (Despotović, Glišin 2021, 315-7). Jovan Cvijić, a renowned Serbian geographer, related that this space was denominated by medieval geographers as the Hellenic (Jelinsko) or Byzantine Peninsula, to become later known as European Turkey, after the conquests of the Anatolian Turks. Later, the Balkans - a name given by the German geographer Zeune in the year 1808 - was adopted in the second half of the $19^{\text {th }}$ century. Zeune has sought to give the geographic name (as was adopted for the Italian peninsula Apennine, and the Iberian got the name Pyrenean). (Cvijić 1991, 4-5). With time, according to the infamous fame of Turks, as Goldsworthy mentions, in West European perception, "the adjective 'Balkan' can imply the opposite of European.” (Goldsworthy 2013, ix) The term Balkan was the source of the term 'Balkanization'. Why? The rebellious spirit, the fight for the liberation and unification of the Balkans people, causing the disintegration of two empires (Ottoman and Austro-Hungarian) looked through imperial glances (in particular through the British) came to be associated with something barbaric and uncivilized. The division of empires and the creation of small nation states were negative in the eyes of Western European imperial planners. Thus, instead of being considered as the cradle of European and Mediterranean civilisation, it became an association with something barbaric. That is because of the perceptions that shape partially the will of the decision-makers, those holding institutional (statesmen, politicians) and non-institutional power (those who

\footnotetext{
${ }^{2}$ See more on that in: Janković, Slobodan. (2019). "Nato Road to Serbia: Why 1999?”, in: Nebojša Vuković (ed.), DAVID vs. Goliath: NATO war against Yugoslavia and its implications, Institute of International Politics and Economics: Faculty of Security Studies,- Belgrade, Novi Sad: Mala knjiga +. pp. 155-176.
} 
control key shares in the largest corporations and hedge funds, heads of formally non-governmental influential think tanks such as the Council of Foreign Relations or Chatham House).

Regarding space and its features important for the hunger of the elites for territories and their resources, the first obvious fact is that the geographic Balkans is south of the rivers Sava and Danube. Still, because of the historic legacy of Greek-Byzantine and Ottoman influences, Romania is also counted among the Balkan nations. The surface is counted differently. It may be $505.578 \mathrm{~km}^{2}$, but also more or less. ${ }^{3}$ For example, Glišin claims it has $520.000 \mathrm{~km}^{2}$. (Glišin 2019, 54). Both estimates refer to territory not counting in Romania, but variations depend on whether one counts a small part of Slovenia and a minuscule part of Italy. It has 50 to 70 million people. ${ }^{4}$ This different information on the size derives from differently assessed borders of the Peninsula. They are quite murky on the north-western side, where they follow the river Kupa, or part of the Alps. The Black Sea in the east, the Adriatic Sea in the west and the Aegean Sea, the Bosporus and Dardanelles in the south are natural borders of the Peninsula. Thus, states which are entirely or partially in the Balkans are Slovenia, Croatia, $\mathrm{BiH}$, Montenegro, Albania, Greece, Serbia, Macedonia, Bulgaria, and Turkey.

The most important geographic features are communication lines: a) the old via Egnatia (now controlled mostly by Americans) from the Albanian port of Dyrrachium to Constantinople; b) the via Militaris, a natural road from Belgrade following river valleys, passing through Niš, Sofia, and arriving in Constantinople; and c) the river Danube, connecting central Europe and the central part of the Balkans with the Black Sea. The European Union has also projected other significant roads to connect Western Asia with central Europe through Budapest, passing through Belgrade, which opens up the road toward Vienna and the ports of Trieste and Koper (Italy and Slovenia). ${ }^{5}$ These roads and the history of the region as a borderline for many centuries continue to be essential features. Still, the Peninsula has also added other characteristics, such as a contact region and a knot of interests. ${ }^{6}$ Proroković adds the 'magnetic' character of the Balkans, in a

\footnotetext{
${ }^{3}$ It depends whether one counts the geographic Balkans, only countries that are entirely or mostly in the Peninsula, or the 'cultural' Balkans with Romania.

${ }^{4}$ Population total: Greece, Bulgaria, Serbia, North Macedonia, Albania, Montenegro, Bosnia and Herzegovina, half of Croatia: 38 million +20 millions of Romania and Turkey 11,961,338 (estimation 2019).

${ }^{5}$ On the subject of the EU roads see in: Glišin Vanja. 2019. Balkanska geopolitickea paradigma, Kairos 2019, p. 56.

${ }^{6}$ On the mentioned characteristics of the Balkans, and the authors who wrote on it, from Šušnjić to Gajić, Despotović, Grčić, Stepić and Knežević, see a chapter in Vanja Glišin. 2019. Balkan Geopolitical Paradigm (Балканска геополитичка паралигма: Балкан у геополитичкој визури великих сила), Kairos: Sremski Karlovci, п. 56-60.
} 
sense of attracting the intrusion of great powers. (Prorokovic 2017, 413). In the view of classical geopolitics, it is part of the Rimland - an area named by DutchAmerican Spykman, who was looking to understand the world as it was in the 1940s and deemed it crucial for ruling Eurasia. (Spykman, 1969, 43). But his understanding had little to do with the Balkans as he was researching the ways for the US to dominate the world and offered world level analysis. ${ }^{7}$ The Rimland refers to vast territories of which the Balkans are only a small, but arguably important part.

Such a position makes it interesting for the trafficking of narcotics and illegal migrants. The former socialist Yugoslavia, and since the 1990s, the states formed after the destruction and dissolution of Yugoslavia, have acquired rising importance in the illegal trade not only from Asia to Europe, but, in recent years, also partly of cocaine from South America to parts of the European black markets. (McDermot et al. 2021, 32-35, 62).

Besides these types of goods trafficked illegally, the Peninsula holds some rich and even strategic deposits of ores. Mining ores of gold, nickel, lithium, copper and others are important, in particular in Serbia and Romania. In the Serbian province of Kosovo, at the heart of the Balkans, the estimated value of different minerals and mining ores is around 1000 billion USD. (Janković 2018, 37). The Balkans are on the road from Asia Minor to Central Europe and, via the Aegean and the Mediterranean Sea, has communication also with the Levant and North Africa. Deposits of ore rich in lithium in western Serbia are estimated at 10 percent of the world's deposits of the ore essential for creating batteries for electric transport vehicles. (Nuttall 2021).

From the local point of view, these historical and geographic features make the Balkans an important and increasingly interesting theatre for the actions of actors on a global, regional, and local scale because it represents the crossroads of political, economic, and criminal interests on a wider scale.

\section{THE PLACE OF THE BALKANS IN THE BROADER GEOPOLITICAL CONTEXT}

After presenting the crucial historical and geographic characteristics, one should proceed to review the interests and presence of the crucial geopolitical actors in the region. Relations of cooperation and confrontation may be studied as a battle of global elites against the peoples, or traditionally as relations between

\footnotetext{
${ }^{7}$ For example, he mentions Yugoslavia and offers its map (Map 20) in order to demonstrate the dangers of encirclement. (Spykman 1969, 22-23).
} 
nations and other international actors. For the purpose of the paper, the second approach is adopted.

All three great powers, the US, Russia, and China, are active in the Peninsula, and their geopolitical interests will be briefly presented. Besides them, corporations are indeed important, but whether we are more akin to realists, constructivists or the liberalist school of thought, it is safe to say, for the purpose of the paper, that countries implement policies in line with the interests of major corporations (or corporations follow them). The role of Germany or Turkey will be briefly mentioned. Finally, local players will be presented.

Just as Eastern and Central Europe, the Balkans has recently witnessed:

"a twofold transition, social and geopolitical. Social is in the sense of change of the global social system and of models of social development... Geopolitical transition of the Balkans is reflected in the reorientation of the most of its countries westward and start of the euro-integrations. Geopolitical result of these changes is ... NATOisation of the Balkans, protectorisation of the said geospace, marginalisation of the Russian influence..." (Mitrović 2008, 11).

These processes put the Balkans in the broader context of the control of the European part of the Rimland in order to solidify the front toward Moscow, emphasized after Putin came to denounce American prepotency in his speech at the Munich Security Conference in 2007. Looking back at the beginning of the 1980s, David Fromkin, regarding the Afghan intervention by the Soviet Union, published a paper on the history of the Great Game, the Anglo-Russian rivalry in Asia. (Fromkin 1980). But, if we could attribute this term as a general term for the rivalry or, better, for the confrontation between Russia and the West, then we may also apply it to the West-Russia confrontation in the Balkans. Years ago, in Europe, the main theatre of that confrontation was eastwards of the Balkans. Starting with the new Ukrainian crisis in 2014, Western confrontation with Russia erupted again in the former centre of Russian civilisation, in Kiev. That is when groups of protesters, including Nazi-style radical groups, staged mass protests and again overthrew the legal president in what was known as the Maidan protests. (Cohen 2018; BBC 2014). Crimea separated and joined Russia, and the war in the eastern parts of Ukraine erupted. The revived great game between Russia and Westerners continued. But despite the pressure inside what was once tzarist Russia and afterwards the USSR, Moscow continued its policy of playing behind immediate contact lines with NATO.

This demonstrates how politics in a certain space is often a result of the will of great powers (external to the Balkans) to implement them and their ability to use them. The history here is important because, without it, there would be no reason for the West to see Serbs as inherently small Russians (Stepić 2012, 205) 
or at least as their allies, or for Bulgarians to further claim the identity of North Macedonian Slavs. Equally, Russia could not expect Serbian governments to be induced by popular opinion to cooperate with Moscow.

After the dissolution of the Warsaw Pact, the West continued to expand eastward by means of the EU and NATO. But at that moment, the collapse of the pluridecennial rival gave the American president an opportunity to proclaim the new world order. In parallel, what occurred in central Europe was the unification of Germany and the will of its leadership to assert the united country as a European power.

Russian politics in the Balkans fits into the general policy of relocation of conflict away from the borders. By doing so, Moscow is able to move part of the pressure away from itself and cherish good relations with its partners, showing it can guarantee its partners. This is part of the explanation why Russia became engaged in Syria (since 2015), and in Libya, if not before, then since 2018. (Lenta.ru, 2018). The Russians did not accomplish anything similar in the Balkans as in the Middle East. There was no occasion for such an endeavour. Yet, it insisted on developing gas corridors at the bottom of the Baltic and North Seas, across the Black Sea and the Balkans, crossing Turkey, Bulgaria, and Serbia. Diplomatic support and energy policy of Russia towards Serbia and their economic engagement with Bulgaria were enough for Western think tanks to advise policymakers in the White House in 2016 to "prioritize combating Russian influence" (Conley, 2016, 32). This approach of self-mirroring, where any action or simple diplomatic words serve to recreate an image of some growing alien presence, in this case, Russia, is witness to paranoia and ideologically driven analysis in the United States. However, actions are being taken after such types of studies.

The role of big powers in contemporary Balkan politics is also induced by their contact position, the role of the Bosporus and Dardanelle straits through which the Russian Black Sea operates in the East Mediterranean and the western fleets pass and provoke Russia by organising military marine drills. If the Balkans is the playground for the Russian bypass of NATO and NATO-allied countries from Ukraine to Romania, then for the West, NATO and the EU, a part of the Balkans represents possibly Russian-allied and influenced territories. In this context, if we look at the map of NATO (and also of the EU) in the Balkans, it clearly shows circled Serbian positions as an island supported diplomatically by Russia. These different perspectives on the same region partially perpetuate the designated role of some of the local actors. The main Russian diplomatic partners in the region are Serbia and the Republic of Srpska (the Serbian entity in Bosnia and Herzegovina, BiH). Similarly, like Russia, China invests in the Balkans and has developed particular ties with Serbia, as the only country besides BiH which is outside of NATO. 
This activity of the great powers, and of the EU as a key economic partner of the Balkan countries, has influenced infrastructural investments in the Balkans: a) expansion of the highways in Serbia, Bosnia and Herzegovina, North Macedonia, and Greece and a project to build one from Tirane, the capital of Albania, through Priština to Niš (south-east Serbia); b) investment in military infrastructure in Greece; and c) Chinese interest in developing continental connection from Budapest to the port of Piraeus.

\section{THE GREAT POWERS AND THE BALKANS SINCE 2019}

\section{Russia}

In the mentioned period, Russia was in a diplomatic row with the West and Ukraine at the top of current affairs. The EU constantly renews sanctions on Moscow "adopted in response to the illegal annexation of Crimea and the deliberate destabilisation of Ukraine." (bold words are original). (Council of the European Union, 2021). While Germany continues its policy of cooperating with Russia regarding gas, when Trump, the then U.S. president, called for the return of Russia to the G7 (ostracised after the separation of Crimea from Ukraine), it was Berlin, according to its uncharismatic minister of foreign affairs, Heiko Mass, who was against it. (Brzozowski 2020). Brussels, following the objectives of transatlantic elites, puts pressure on the Balkan countries not to cooperate with Russia and to impose sanctions. The only two countries resisting such pressure are $\mathrm{BiH}$ and the Republic of Serbia. (Pivovarenko, 2019). Russian support for Serbian interests and the position of Serbs on the status of the Republic of Srpska (in $\mathrm{BiH}$ ) and Kosovo and Metohija is supported by investment projects, arms modernisation, diplomatic cooperation, and cooperation and support for the growth of bilateral trade. In January 2019, Russian president Putin assisted in the signing of more than 20 memoranda of cooperation. (Ivanov 2019). The Russian state railways project of building more than $400 \mathrm{~km}$ of railways is the most significant, together with the construction of the Balkan stream (BS is a part of the Turkish stream). As regards the latest project, it was silently connected in January 2021, with the connection of pipelines between Serbia and Bulgaria. With this, Moscow has achieved two things: 1) three Balkan states are more closely connected to Russia, at least in the field of energy cooperation, and will have a transit fee - Serbia, Bulgaria, and Turkey. (MFA 2021); 2) Russia managed to bypass Ukraine and have more leverage in its relations both with Kiev and Brussels. The plan is to send Russian gas to Central Europe - and the infrastructure for that is ready as pipes between Serbia and Hungary will be connected in July 2021 — via Serbia and eventually to Italy if 
TAP (Trans Adriatic Pipeline) does not start. (Аенькович 2021). This secures longer Russian influence in the central Balkans (see Map 1).

Map 1. Russian gas pipeline in the Balkans

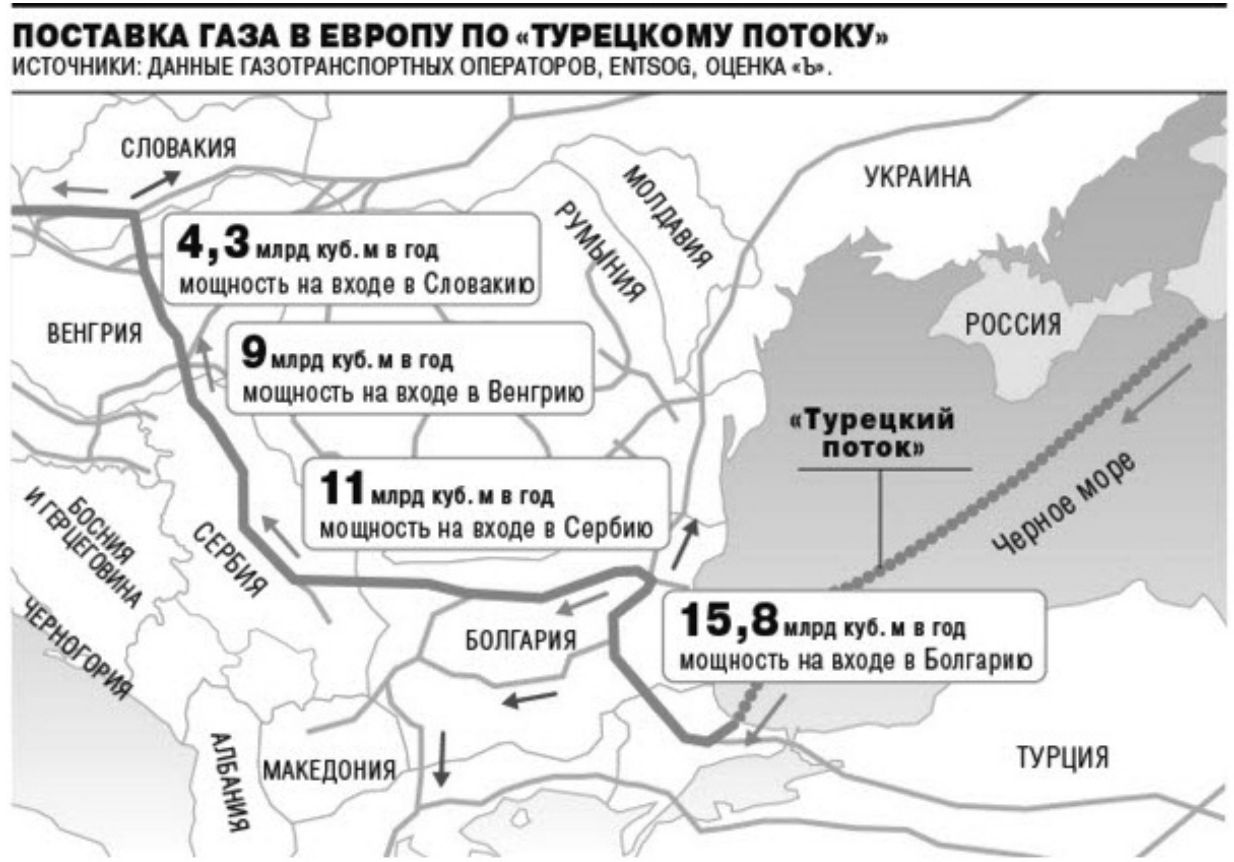

source: Русская Болгария, 22 ноября, 2018, https.//rus.bg/ekonomika/ekonomika/24967gazprom-opredelilsya-s-marshrutom-postavki-gaza-po-turetskomu-potoku-kotoryj-projdetcherez-bolgariyu accessed: 10/7/2021.

Besides energy policy, traditionally, Russia has been interested in selling arms and preventing the expansion of NATO. As regards arms, besides the most known selling contract of the S-400 to Turkey, Russia has modernised, sold and donated different military equipment to Serbia. Only in 2021, it donated 30 tanks T-72MC and 30 armoured vehicles worth $€ 75$ mil. With the admission of North Macedonia (a country that accepted to change its name and the names of streets and public buildings, and granted particular rights to the Albanian minority and their language in order to be admitted) to NATO, only two countries remain outside the Alliance, both in the central part of the Peninsula - Serbia and Bosnia and Herzegovina. Along with Albania, Montenegro, and North Macedonia, these countries are also outside the European Union. The constant policy of preventing the expansion of NATO has obviously failed, with non-NATO countries being surrounded. 
Russia managed to partially use the Covid-19 crisis to launch its medical help and then its vaccine Sputnik V in some countries of the region, which was viewed through a magnifying glass as vaccine geopolitics.

\section{The United States of America}

For US geostrategy, it is essential that NATO controls the shores of all four seas (Adriatic, Ionian, Aegean and Black Sea) on the Balkan littoral. The American grip on the Peninsula goes in four directions: 1) versus Russia, 2) versus Turkey and the Middle East, 3) versus the European Union, and 4) against Chinese penetration.

1) Direction on Russia is part of the old strategy of encircling the enemy and impeding Moscow from having influence and partners, in order not to be able to project power outside the USSR sphere and, ideally, outside its borders. Control of the Adriatic was already secured with the dominant influence of the West over Albania and Italy, the US and the UK allies in the Strait of Otranto.

2) After Turkey started an autonomous foreign policy, the US started to develop closer and more intense cooperation with Greece. This cooperation is the logistical centre for the two triangles, of which one is composed of Greece, Cyprus, and Israel, and the other of Greece, Cyprus, and Egypt. The US investment in the port of Alexandroupolis is aimed at threatening the Turkish/Balkan Stream, and potentially controlling the power projection of Turkey (in the Balkans) and of Russia through the Straits of Bosporus and Dardanelles. It is part of the bilateral defence arrangements that should prepare bases for the eventual repositioning of U.S. forces in the Eastern Mediterranean. The Mutual Defence Cooperation Agreement (of 2020) ${ }^{8}$ between Washington and Athens provides the US with four military facilities in this Balkan country, and negotiations to expand them are underway. It already includes usage of two military bases in Thessaly, Larissa Air Base and Stefanovikio Army Aviation Base, along with usage of the port of Alexandroupolis and the expansion of Souda Bay naval and aviation facilities on the island of Crete. (GOA 2019). The eventual expansion would include more military facilities in Greece to be used potentially by American military forces. Economically, the US enforced the activities of its consulate in Thessaloniki. Elisabeth Lee, heading this consulate in October 2020, emphasized that:

\footnotetext{
${ }^{8} \mathrm{It}$ is, in fact, an ammendment to the Agreement of 1990.
} 
"The United States considers Greece a pillar of stability in the region, a country that is vital to our strategic interests." Lee also pointed out that the US Ambassador to Greece, Geoffrey Pyatt, has visited Alexandroupolis five times during his tenure, "more than any other US ambassador in history." (GCT 2020).

3) Engagement versus the EU can be seen in enforcing the US influence in the Balkans, on the European continent. The US did that in Ukraine in order to show that the big boss is in Washington and the US is the one who makes decisions, not Brussels. Thus, Washington is crucial in negotiations between Belgrade and Priština. The US is the main security partner of Bulgaria, Romania, Greece, and Albania. It is Washington who approves the EU representative in Bosnia and Herzegovina. It was the United States and not the EU that used its leverage in order to induce Greece and Skoplje to firm up the Prespa Agreement and achieve membership of North Macedonia in NATO.

4) The US presence in Greece and, in particular, the building of its infrastructure in the northern part of the country is aimed at curbing Chinese power projection from the port of Piraeus towards North Macedonia, Serbia and Central Europe.

These policies and further American engagement were officially announced by the White House in the readout of the call between U.S. President Biden and the President of the EU Commission, Von der Leyen. (White House, 2021). In that short statement, it was said that "close US-EU ... leaders also agreed to coordinate on issues of shared interest, including China, Russia, Belarus, Ukraine, and the Western Balkans." (same). 
Map 2. Trimarium and two 'triangles':

U.S. partnerships from Baltic Sea to Levant

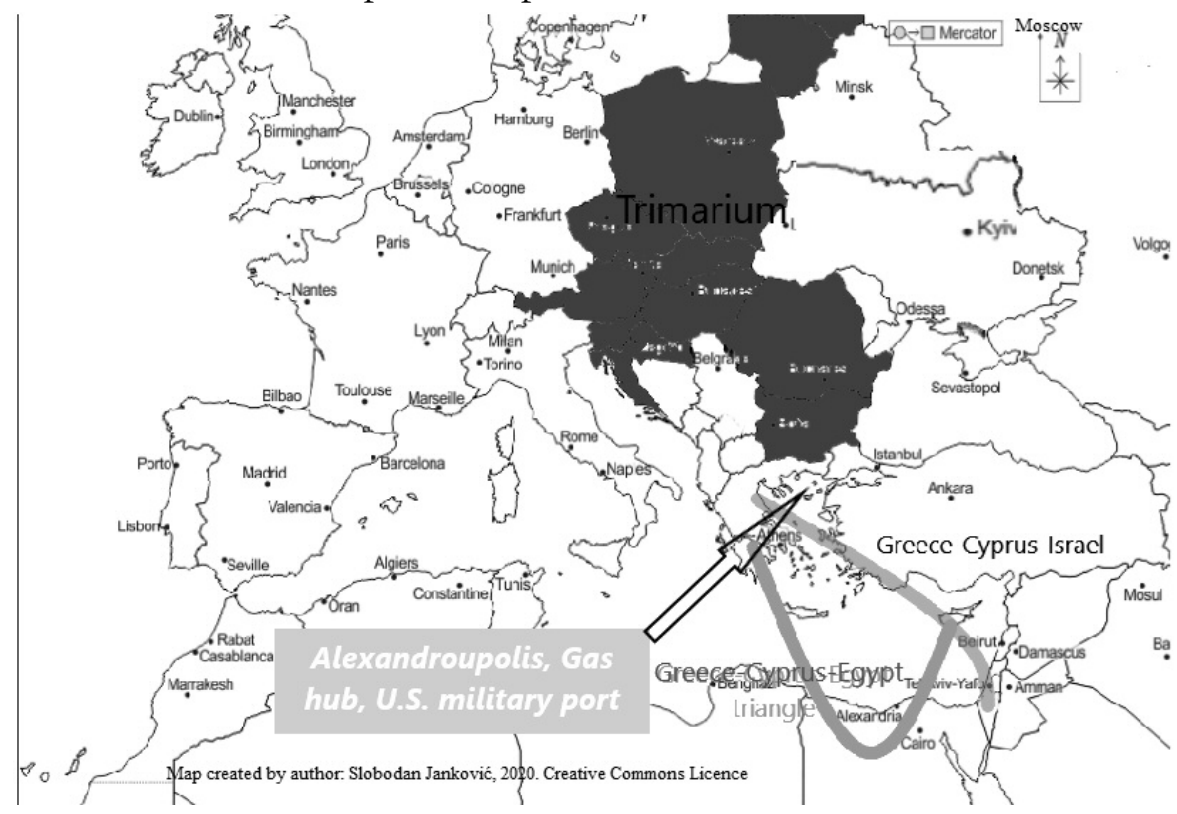

As is visible on the map, Greece is a place where one U.S. supported initiative - Trimarium, connecting the Baltic Sea to the Adriatic and Black Seas - which is a revival of the Intermarium in the period between the two world wars (as it fulfils the same purpose of inserting a block between Russia and Germany) is continued with two tripartite partnerships supported by the US. ${ }^{9}$ Hence, Greece, a NATO country, connects this American project with the Levant through two new local coalitions. ${ }^{10}$

\section{China}

The Chinese presence and politics in the Balkans in the mentioned period is a continuation of the New Silk Road economic expansion, relying both on the continental and maritime traits of the Belt and Road (the new name for the initiative launched in 2013). China is using its 17+1 - now turned 16+1 (with Lithuania pulling out) cooperation and direct contact with leading parties in the

\footnotetext{
${ }^{9}$ Though Germany has changed drastically, it is hard to say that it can ever again pursue any policy independent of the West.

${ }^{10}$ Although representatives of the EU Commission and Germany participate on a yearly basis.
} 
region to firmly establish its influence and enforce it. But in the past two years, this fabric has been shaken. Not only did Lithuania leave, but six leaders decided not to participate in the yearly summit. The EU countries, the members of the club, supported the sanctions against China. For the moment, three countries are the most solid Chinese partners - Hungary, Serbia and Greece. ${ }^{11}$ Although China tries to play on economic cooperation and not to get involved in political conflicts, growing tensions on a global scale induced the Ministry of Foreign Affairs in Beijing to announce that "China would like to remind NATO that they still owe a debt of blood to the Chinese people... The dead have passed away, but the living need more vigilance and reflection." (Global Times 2021).

Yet, the expansion of the Chinese economic presence in the Balkans in this period coincides with heavy debt connected to the Covid-19 crisis. The activities of the Bank of China through its Luxembourg subsidiary are tied to Chinese projects. In the Balkans, it has three branches, in Greece, Romania and Serbia, where it operates exclusively for corporate clients. (The Banks, 2021). In order to be able to send goods to central Europe, the Chinese imperative is to complete the railroad from Piraeus to Budapest. Western European markets are within a reach of the ports of Genoa and Trieste, where China is also investing. In this area, there is a problem with the highway in Montenegro (Bar-Boljare) and in North Macedonia (Kičevo-Ohrid).

Table 1: Amount of trade (selected countries)

with the great powers and Germany in 2019 and in 2020.

\begin{tabular}{|c|c|c|c|c|c|c|c|c|}
\hline \multirow{2}{*}{$\begin{array}{c}\text { Balkan } \\
\begin{array}{c}\text { Country } \\
\text { trade } \\
\text { (in millions } \\
\text { USD) }\end{array}\end{array}$} & \multicolumn{2}{|c|}{ With Germany } & \multicolumn{2}{|c|}{ With Russia } & \multicolumn{2}{|c|}{ With the US } & \multicolumn{2}{|c|}{ With China } \\
\cline { 2 - 9 } & 2019 & 2020 & 2019 & 2020 & 2019 & 2020 & 2019 & 2020 \\
\hline Albania & $448(5)^{12}$ & $579(4)$ & $123(10)$ & $148(8)$ & $140(9)$ & $\mathrm{N}^{*}$ & $692(3)$ & $546(6)$ \\
\hline Greece & $9114(1)$ & $9300(1)$ & $4309(5)$ & $3524(6)$ & $2780(10)$ & $2420(11)$ & $5545(3)$ & $5249(3)$ \\
\hline Romania & $35700(1)$ & $35400(1)$ & $4610(12)$ & $2995(14)$ & $2768(16)$ & $2240(15)$ & $5930(7)$ & $6683(6)$ \\
\hline Serbia & $6090(1)$ & $6080(1)$ & $3410(3)$ & $2481(4)$ & $791(20)$ & $811(18)$ & $1891(5)$ & $3667(3)$ \\
\hline
\end{tabular}

Sources: Trading Economics and the Observatory of Economic Complexity (OEC)

* Unknown data

${ }^{11}$ For the sanctions and the crisis inside the format 17+1 see: Kavalski Emilian. 2021. "Quo Vadis Cooperation Between China and Eastern Europe in the Era of COVID-19?", World Affairs. 2021, Volume: 184 issue: 1, pp. 33-56. doi:10.1177/0043820021991116

${ }^{12}$ At the list of trading partners. For example (1) means the first trading partner. 


\section{Germany}

Germany is following transatlantic (another name for transnational) interests. When Trump was substituted by the new government and the US returned to globalist policies, the European Union and Germany, as its economic motor, rejoiced. In this period, Berlin is following its policy of economic domination of the markets, which may be used for political influence. Trade domination is thus a tool that ties Balkan countries to Germany and the EU. Table 2 shows the value of trade between selected Balkan countries and the great powers and Germany. Besides trade, other aspects, such as the transfer of German-owned production in Serbia and Romania, play a significant role in the local economies. Yet, this is not translated into political influence wielded by great powers, which indicates that the will to act, but also the means which may be of non-transparent nature (through intelligence, secret arrangements, semi-secret societies) are above mere economics in (international) politics. Germany is the first trade partner of all Balkan countries except Albania and Montenegro (Trading Economics, 2021).

\section{Turkey}

Turkey has dispersed its armed forces, intelligence, and other resources in the Middle East, North Africa, and the Caucasus, with engagements in Syria, Iraq, Libya, and Azerbaijan, besides already maintaining a significant military presence in other countries. It continues to support its partners among the Muslim populations in Bosnia, in Albania, in Serbia (in particular, among Kosovo Albanians) and elsewhere. Continued clashes with Greece and Cyprus over territorial waters and the delimitation of the exclusive economic zones with the deployment of warships and tensions on the continental border with Greece over the migrant crisis are impeding any stronger Balkan initiative from Ankara in the observed period. Having its multivector policy strengthened, among other directions in the Balkans, Turkey, for the time being, is maintaining its strategic depth by cultivating ties with the Muslim population and waiting for the opportunity to return as a more assertive player.

\section{Balkan countries}

As already noticed above, the majority of the countries on the Peninsula are members of the transatlantic integration, mostly of NATO. Serbs and Albanians are on opposite sides, but neither of their homeland countries is in the EU. Serbia and the Republic of Srpska are historical allies of Russia. Western support for all secessionist movements in the territory of the former Yugoslavia at the expense of Serbian interests, and finally, NATO aggression on Serbia and Montenegro 
in 1999, enforced good relations with Russia. Greece, in its altercations with Turkey, seeks support from Washington and not from Brussels, unable to cope with Turkey. Hence, Athens but also North Macedonia, where Washington's diplomacy was the key to the changing name and the agreement with the Albanians to push the country into NATO. In this period, the status of the Serbian secessionist province of Kosovo and Metohija, along with the office of the High Representative in Bosnia and Herzegovina, are at the centre of the clashing interests of the great powers. It was witnessed lately by the opposite standings of the Western camp and Russia and China regarding the imposition of a German politician as a new international envoy acting as a sort of a governor in Bosnia and Herzegovina. (Sputnik.rs, 2021). All of the peninsula is struck by deep demographic erosion, as many young people, and especially skilled people, have left the region. While Serbia and the Serbian people are generically still in their defensive policies, the Albanian factor is still playing across North Macedonia, the province of Kosovo and Metohija, and with a low profile in Montenegro. Potentialities for geopolitical restructuring still exist and are activated in this period through a series of non-papers following more or less the logic launched by Less in 2016 (see more in the first part of the text). A Slovenian non-paper (informal document, aide-mémoire) titled The Western Balkans - a way forward was published by a local media outlet and it is suspected of being created in the office of Slovenian Prime Minister Janša. It presupposes changes in borders in the so-called Western Balkans, among them the dissolution of Bosnia and Herzegovina, the division of Macedonia and the annexation of the largest part of Kosovo and Metohija by Albania, all in order to join remnant countries and territories in NATO and the EU. (Cirman, Vukovic 2021). This coincided with old plans elaborated informally at Chatham House in the 1990s, and leaves a sinister outlook for the near future.

\section{CONCLUSION}

The geopolitical position of the Balkans is highlighted in the examined period by growing global rivalry. Moscow and Beijing are building their regional footprints and partnerships in parallel to the EU and Washington. The decision of the elites to create an American foreign policy that would curb Russian and Chinese positions in Europe has led to what can be called a "return" to the Balkans.

As a result of concerted efforts by the US and its EU allies, clients or subordinate partners are trying to limit and eventually block Chinese economic penetration in Europe. As part of these efforts, China is suffering from a crisis in its format 16+1, including Balkan countries. However, Beijing still manages to maintain a crucial direction for its trade in the south-north direction from central Greece to Budapest, with the eventual inclusion of Turkey, depending 
on the result of the relations between the two countries (which is beyond the scope of this paper).

It was the decision of Russian elites to challenge American unilateral policies in 2007 that led them, among other reasons, to build the Balkan Stream, previously obstructed as the South Stream. Once the plans to implement policies promoting a stronger presence in the Balkans were made, Russia followed its traditional and geographically logical direction from Turkey through Bulgaria and Serbia to Central Europe. It is a gas pipeline built along more or less the old Via militaris and continuing north toward Slovakia. At the same time, this pipeline connects countries with a significant population with sympathies towards Russia or with political elites cooperating with Moscow. The US, on the other hand, is acting along the axis North-South, from the Baltic Sea to the shores of the Black Sea, the Adriatic and Egean Seas, trying to halt the penetration of two challenging powers. For that, it has developed or strengthened bilateral, trilateral and multilateral partnerships (with Greece, with two trilateral partnerships, with Trimarium). These partnerships are new tools, or adaptations of the old strategy, employed in the fifties with the Balkan and Baghdad pacts. Basically, these initiatives, and one of their expressions, is the new strategic road, named in line with the American Roman parallel via Carpatia. This road connects Klaipeda in Lithuania to Thessaloniki, in order to block Russia (and the Chinese Belt and Road initiative), with power projection in the direction of the North-South. Still, Russian influence comes from the East and Chinese influence is dispersive (aimed at many points) but with a geographically clear source. Despite being economically dominant in the region, the EU and Germany are politically underrepresented. When it comes to Turkey, it concentrated on activities in other regions (the Caucasus, the Middle East and North Africa) and, for the time being, is simply maintaining its clients.

The decision or willingness of different powers to act based on historical heritage (relationships between Russia and Serbia, or a common position of Serbia and China regarding NATO aggression in 1999), or some geographic feature of the Balkans (its location at the crossroads of continents, cultures, and political blocs) explains foreign actors' actions more deeply. It is a small space compared to other macro-regions, but its divisions leave space for many different actors to be active and contribute to confirming the thesis of Aleksandr Dugin that the Balkans are indeed one of the monitors of world politics.

\section{REFERENCES}

Bardos, Gordon N. 2021. "Washington's Fundamentally Flawed Approach to the Balkans", The National Interest. June 12, 2021. https://nationalinterest.org/ feature/washington's-fundamentally-flawed-approach-balkans-187403 
BBC Newsnight. 2014. "Neo-Nazi threat in new Ukraine: NEWSNIGHT", Youtube, March 01, 2014. https://www.youtube.com/watch?v=5SBo0akeDMY

Brzozowski, Alexandra. 2020. “Germany rejects Trump's proposal to let Russia back into G7” EURACTIV.com, July 27, 2020. https://www.euractiv.com/ section/global-europe/news/germany-rejects-trumps-proposal-to-let-russiaback-into-g7/

Ceremigna Jasmine. 2019. "Stati Uniti: il ritorno di Washington nella geopolitica dei Balcani”, Sicurezza Internazinale, Settembre 3, 2019. https://sicurezza internazionale.luiss.it/2019/09/03/stati-uniti-ritorno-washington-nellageopolitica-dei-balcani/

Cirman Primož and Vesna Vuković. 2021. "Objavljamo dokument o razdelitvi $\mathrm{BiH}$, ki ga išče ves Balkan”, Necenzurirano.si, April 15, 2021. https://necenzurirano.si/clanek/aktualno/objavljamo-slovenski-dokumento-razdelitvi-bih-ki-ga-isce-ves-balkan-865692

Cohen Josh. 2018. “Commentary: Ukraine's neo-Nazi problem”, Reuters, March 19, 2018. https://www.reuters.com/article/us-cohen-ukraine-commentaryidUSKBN1GV2TY

Conley, Heather A, James Mina, Ruslan Stefanov, Martin Vladimirov. 2016. The Kremlin Playbook: Understanding Russian influence in Central and Eastern Europe, A Report of the CSIS Europe Program and the CSD Economics Program: Center for Strategic and International Studies, October 2016.

[CEU] EU restrictive measures in response to the crisis in Ukraine, Council of the European Union, June 23 2021. https://www.consilium.europa.eu/en/ policies/sanctions/ukraine-crisis/.

Despotović, Ljubiša and Vanja Glišin. 2021. Савремени међународни односи и геополитика (Contemporary International Relations and Geopolitics), Каирос: Нови СаА

Екмечић МилораА.(Ekmečić Milorad). (2010). Ауго кретане између клата и орать: Историја Срба у Новом веку 1492-1992, (Long walk from butchering to plowing: History of the Serbs in Modern period, 1492-1992). Службени ГАасник 2010.

Fromkin, David. 1980. "Great Game in Central Asia”, Foreign Affairs Vol. 58, No. 4, Council on Foreign Relations, pp. 936-952.

GCT. 2020. "Greece is not alone, says US Consul General in Thessaloniki”, Greek City Times, October 12, 2020. https://greekcitytimes.com/2020/10/12/ greece-is-not-alone-says-us-consul-general-in-thessaloniki/

Glišin, Vanja. 2019. Balkan Geopolitical Paradigm (Балканска геополитичка парадигма: Балкан у геополитичкој визури великих сила), Kairos: Sremski Karlovci 
Global Times. 2021. "US-led NATO still owes blood debt to Chinese people: FM", Global Times, Mar 26, 2021. https://www.globaltimes.cn/page/ 202103/1219540.shtml

Goldsworthy, Vesna. 2013. Inventing Ruritania: the imperialism of the imagination. London: Hurst \& Company.

Huntington, Samuel P. 1996. The Clash of Civilizations and the Remaking of World Order. New York, NY: Simon and Schuster.

Janković, Slobodan. 2010. "Borders in The Balkans: Longevity in the Postmodern Era", in the Collection of Papers Serbia In Contemporary Geo-Strategic Surroundings, edited by Slavica Đerić-Magazinović and Nevenka JeftićŠarčević, Institut za međunarodnu politiku i privredu i Ministarstvo odbrane RS, Belgrade 2010, pp. 165-178.

Janković, Slobodan. 2018. "I confini balcanici: lo stato nazione e il riordino Europeo nel caso serbo", edited by Slobodan Janković, Grandi stati, grandi nazioni e immaginari geopolitici nei Balcani, Geopolitica, rivista semestrale dell'Isag, Vol. VII - Nº 2 / Lugl. - Dic. 2018, pp. 29-56.

Janković, Slobodan. 2019. "NATO Road to Serbia: Why 1999?", edited by Nebojša Vuković, David vs. Goliath: NATO war against Yugoslavia and its implications, Institute of International Politics and Economics : Faculty of Security Studies, Belgrade, Novi Sad: Mala knjiga. pp. 155-176.

Kavalski, Emilian. 2021. "Quo Vadis Cooperation Between China and Eastern Europe in the Era of COVID-19?”, World Affairs. 2021, Volume: 184 issue: 1, pp. 33-56. doi:10.1177/0043820021991116

Lake, David A. 2009. Hierarchy in International Relations, Cornell University Press.

Lake, David A., Lisa L. Martin, and Thomas Risse. 2021. "Challenges to the Liberal Order: Reflections on International Organization." International Organization 75, no. 2, pp. 225-57. doi:10.1017/S0020818320000636.

Lenta.ru (2018). "Раскрыты подробности российского военного присутствия в Аивии", октября 9, 2018. https://lenta.ru/news/2018/10/09/libiya/

Less, Timothy. 2016. "Dysfunction in the Balkans. Can the Post-Yugoslav Settlement Survive?", Foreign Affairs, December 20, 2016. https:// www.foreignaffairs.com/articles/

Marconi, Matteo. 2012. "Spunti di riflessione su geopolitica e metodo: storia, analisi, giudizio", Geopolitica, rivista semestrale dell'Isag, No. 3, 2012, pp. 47-64.

McDermott, Jeremy, James Bargent, Douwe den Held and Maria Fernanda Ramírez. 2021. The Cocaine Pipeline To Europe, Global Initiative Against Transnational Organized Crime and Insight Crime. Research Report February 2021, pp 68. 
[MFA]. 2021. "New "Balkan Stream" gas pipeline opened", Ministry of Foreign affairs of the Republic of Serbia, January 6, 2021. http://www.moskva. mfa.gov.rs/odrzavanje/stampa.php?id=1609932658\&archive

Mitrović, Ljubiša. (2008). "Geopolitička tranzicija Balkana i nove Evrope i njihova uloga u uslovima monocentrične globalizacije sveta”, Ekonomika, Niš, 2008, Year LIV, N. 3-4, pp. 9-14.

Nations online project. Political Map of Balkan Peninsula, parts of the Mediterranean Sea, and the Black Sea Region, https://www.nations online.org/oneworld/map/Balkan-Peninsula-Map.htm

Nuttall, Clare. 2021. "Miners tap Western Balkans for crucial EV battery ingredient lithium", February 1, 2021. https://www.intellinews.com/minerstap-western-balkans-for-crucial-ev-battery-ingredient-lithium-201673/

Пивоваренко, Александр (Pivovarenko Aleksandr). 2019. "БАистательность сербского маневрирования”, (Russian Council) Российский совет по межАународным делам. 11 декабря 2019. https://russiancouncil.ru/analytics -and-comments/analytics/blistatelnost-serbskogo-manevrirovaniya/.

Proroković, Dušan. 2017. "Geopolitičke determinante spoljnopolitičkog pozicioniranja Srbije na početku 21. veka", (Geopolitic determinants of the foreign policy positioning of Serbia at the beginning of the 21st century ), Medunarodni problemi, Vol. LXIX, br. 4, str. 401-422. https://doi.org/ 10.2298/MEDJP1704401P

[SD] Protocol Of Amendment To The Mutual Defense Cooperation Agreement Between The Government Of The United States Of America And The Government Of The Hellenic Republic, State Department, Government of the United States of America, October 5, 2019, https://www.state.gov/wpcontent/uploads/2020/07/20-213-Greece-Defense-TIMS-62163.pdf

Sputnik. 2021. "Savet bezbednosti nije podržao rusko-kinesku rezoluciju o BiH", Sputnik.rs, July 22, 2021. https://rs-lat.sputniknews.com/20210722/savetbezbednosti-nije-podrzao-rusko-kinesku-rezoluciju-u-bih-1127665364.html

Spykman, Nicholas John. 1969. The Geography of the Peace, Archon Books

The Banks. 2021. "European Presence: 21 banks in 18 countries", The Banks, https://thebanks.eu/banks/19140/locations

[OEC], 2020.The Observatory of Economic Complexity. https:// oec.world/

Todorova, Maria. 2009. Imagining the Balkans, Oxford University Press

Trading Economics. 2021. https://tradingeconomics.com/

[White House]. 2021. Readout of President Joseph R. Biden, Jr. Call with European Commission President Ursula von der Leyen, March 05, 2021, Statements and releases, https://www.whitehouse.gov/briefing- 
room/statements-releases/2021/03/05/readout-of-president-joseph-rbiden-jr-call-with-european-commission-president-ursula-von-der-leyen/.

ГАишић, Аушан (Glišić Dušan). 2020. “Србија има одговорност за Балкан” (Interview with Aleksandr Dugin), Одбрана, N. 332, February 2020, pp. 48-53.

Аенькович, Ярослава. 2021. "Serbia and Hungary have completed Balkan Stream", Kosatka July 05, 2021.//kosatka.media/en/category/gaz/ news/serbiya-i-vengriya-zavershili-balkanskiy-potok

Русская Болгария. 2018. "Газпром определился с маршрутом поставки газа по Турецкому потоку, который пройдет через Болгарию” (Gasprom decided that route of the gas with Turkish stream shall pass through Bulgaria), 22 ноября, 2018, https://rus.bg/ekonomika/ekonomika/24967-gazpromopredelilsya-s-marshrutom-postavki-gaza-po-turetskomu-potoku-kotoryjprojdet-cherez-bolgariyu Степић, Миломир (Stepić Milomir). 2012. Косово и Метохија - постмодерни геополитички експеримент, Институт за политичке студије, БеограА.

Цвијић, Јован. 1991. Балканско полуострво и јужнословенске земъе, Завод за изАавање уџбеника, Београд.

\section{GEOPOLITIKA BALKANA: 2019-2021.}

Apstrakt: Predmet ovog rada je geopolitička analiza politike velikih sila na i oko Balkana u periodu od tri godine. Autor započinje tekst sa prepričavanjem događaja iz 2019. godine koji je indikativan za jednu od dve hipoteze. Prva je da se Amerika `vratila` na Balkan, a drugu je definisao ruski geopolitičar Aleksandar Dugin, a to je da je Balkansko poluostrvo jedno od dva monitora svetske politike. Tekst je podeljen u pet celina. U uvodnom delu autor definiše hipoteze i odabira italijansku neoklasičnu geopolitičku misao za teoretski okvir. U drugom poglavlju je pružen pregled osnovnih društveno-istorijskih i geografskih osobenosti poluostrva bitnih za geopolitičko poimanje. Treći deo teksta je posvećen stavljanju vođenja balkanske politike spoljnih i unutrašnjih aktera u širi geopoliitčki okvir. Četvrti deo je najduži i u njemu je ukazano na najznačajnije političke aktivnosti velikih sila, Rusije, SAD i Kine, kao i Nemačke, Turske i lokalnih zemalja. Zaključni deo potvrđuje Duginovu pretpostavku i potvrđuje tezu da je politika velikih sila na Balkanu ponovo dobila na značaju za SAD.

Kjučne reči: Geopolitika, Balkanska politika, Ruska balkanska politika, Pojas i put, američke inicijative na Balkanu, Srbija, Grčka, nemačka balkanska politika. 